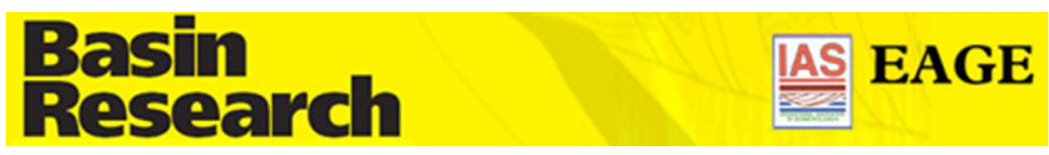

\title{
BASIN TECTONIC HISTORY AND PALEO-PHYSIOGRAPHY OF THE PELAGIAN PLATFORM, NORTHERN TUNISIA, USING VITRINITE REFLECTANCE DATA
}

\begin{tabular}{|c|c|}
\hline Journal: & Basin Research \\
\hline Manuscript ID & BRE-028-2017.R1 \\
\hline Manuscript Type: & Original Article \\
\hline Date Submitted by the Author: & $\mathrm{n} / \mathrm{a}$ \\
\hline Complete List of Authors: & $\begin{array}{l}\text { Cavailhes, Thibault; Universite de Bordeaux, UMR CNRS } 5805 \text { EPOC - } \\
\text { OASU } \\
\text { Rotevatn, Atle; University of Bergen, Postboks } 7803 \\
\text { Monstad, Ståle ; Point resources AS } \\
\text { Ben Khala, Atef; DNO Tunisia AS Le Tanit du Lac, Blocks C\&D Rue du Lac } \\
\text { Windermere, Les berges du Lac } \\
\text { Funk, Erich; DNO International, Dokkveien } 1 \\
\text { Canner, Kathryn; DNO International, Dokkveien } 1 \\
\text { Looser, Mirko; DNO International, Dokkveien } 1 \\
\text { Chalabi, Ali; DNO International, Dokkveien } 1 \\
\text { Gay, Aurélien; University of Montpellier, Laboratoire Geosciences } \\
\text { Travé, Anna; Facultat de Geologia, Universitat de Barcelona } \\
\text { Fehri, Faycel; ETAP, Entreprise Tunisienne d'Activités Pétrolières, 54, } \\
\text { Avenue Mohamed } \\
\text { Skanji, Ahmed; ETAP, Entreprise Tunisienne d'Activités Pétrolières, 54, } \\
\text { Avenue Mohamed } \\
\text { CHEBBI, Mohammed Riadh; ETAP, Entreprise Tunisienne d'Activités } \\
\text { Pétrolières, 54, Avenue Mohamed } \\
\text { Bang, Nils; DNO Tunisia AS Le Tanit du Lac, Blocks C\&D Rue du Lac } \\
\text { Windermere, Les berges du Lac }\end{array}$ \\
\hline Keywords: & basin subsidence, tectonics and sedimentation, structure, foreland basins \\
\hline
\end{tabular}

\section{SCHOLARONE ${ }^{\text {tw }}$}

Manuscripts 


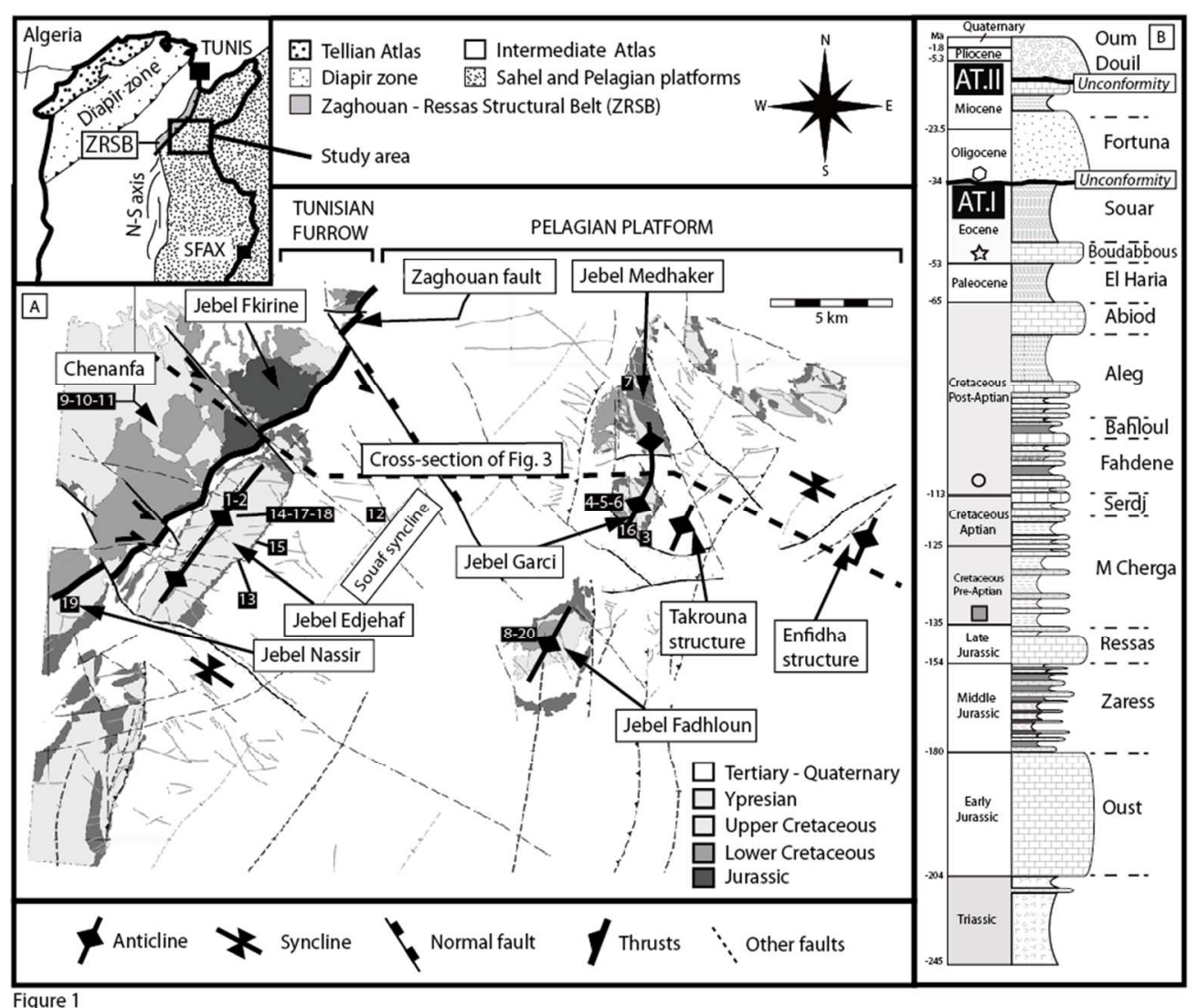

Figure 1: A) Structural sketch of the Enfidha region in Northern Tunisia (see inset map for location) showing toponymy, geologic structures, and ages of strata. The structural sketch has been modified from Turki (1985). The location of the cross-section of Figure 3 is shown. B) Simplified stratigraphy of the studied area with the stratigraphic locations of VR samples (square, circle, star, octagon; see also key in Figure 4 and 5). AT.I = Atlas I tectonic event, AT.II = Atlas II tectonic event. Samples details are given in Table 1. Formation thicknesses and stratigraphic sample locations are also given in Figure 4B.

\section{$355 \times 300 \mathrm{~mm}(72 \times 72 \mathrm{DPI})$}




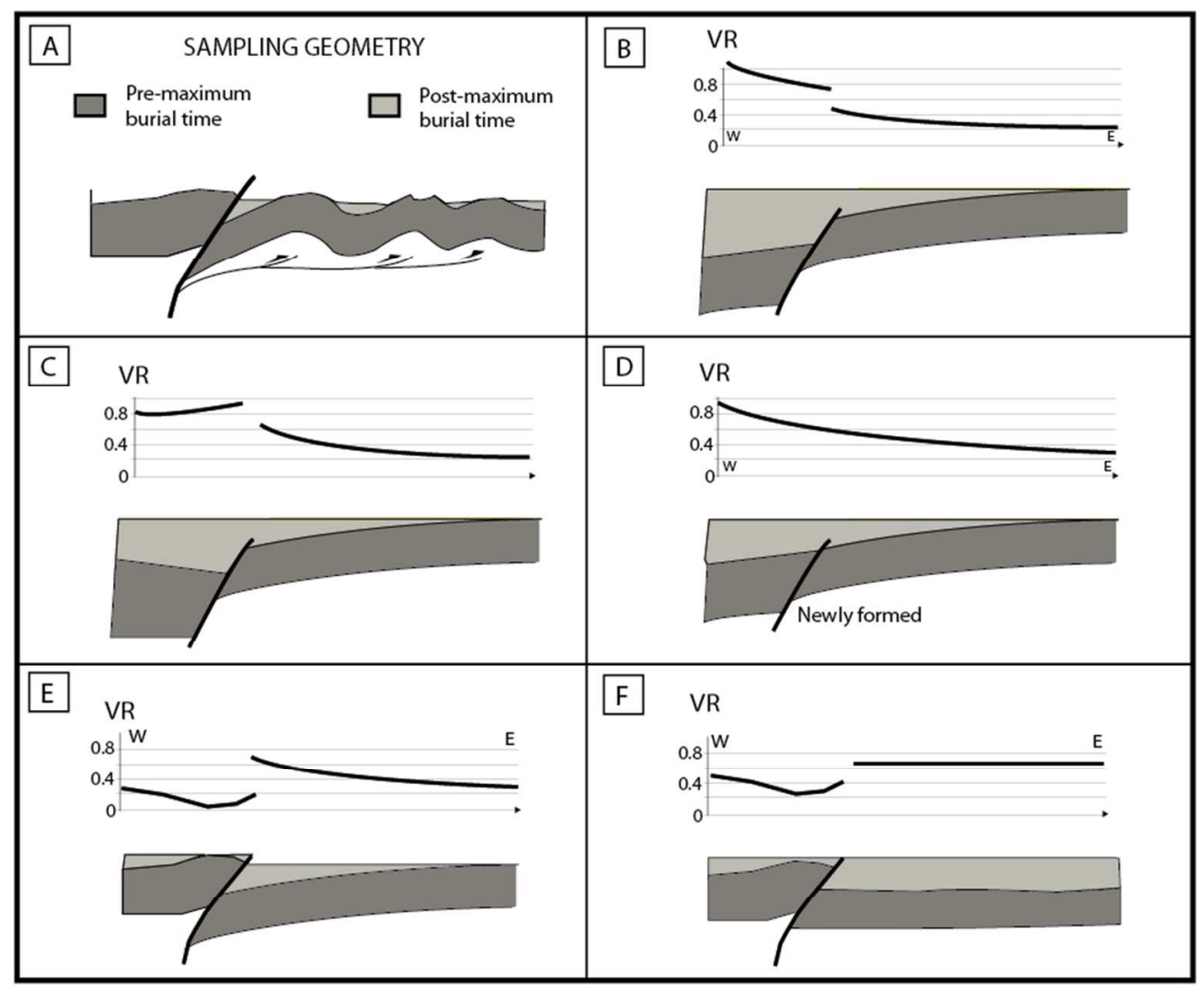

Figure 2

Figure 2: A) Present-day conceptual cross-section of the studied area. Main black fault is the Zaghouan fault. B), C), D), E, F) are hypothetical pre-folding geometries that can be tested using VR data. Indicative VR trend is given for each sketch in order to highlight the methodology followed by the authors to unravel the basin paleo-geometry. In this study, the maximum burial depth (middle to upper Miocene) is inferred from the Figure 3.

\section{$333 \times 283 \mathrm{~mm}(72 \times 72 \mathrm{DPI})$}




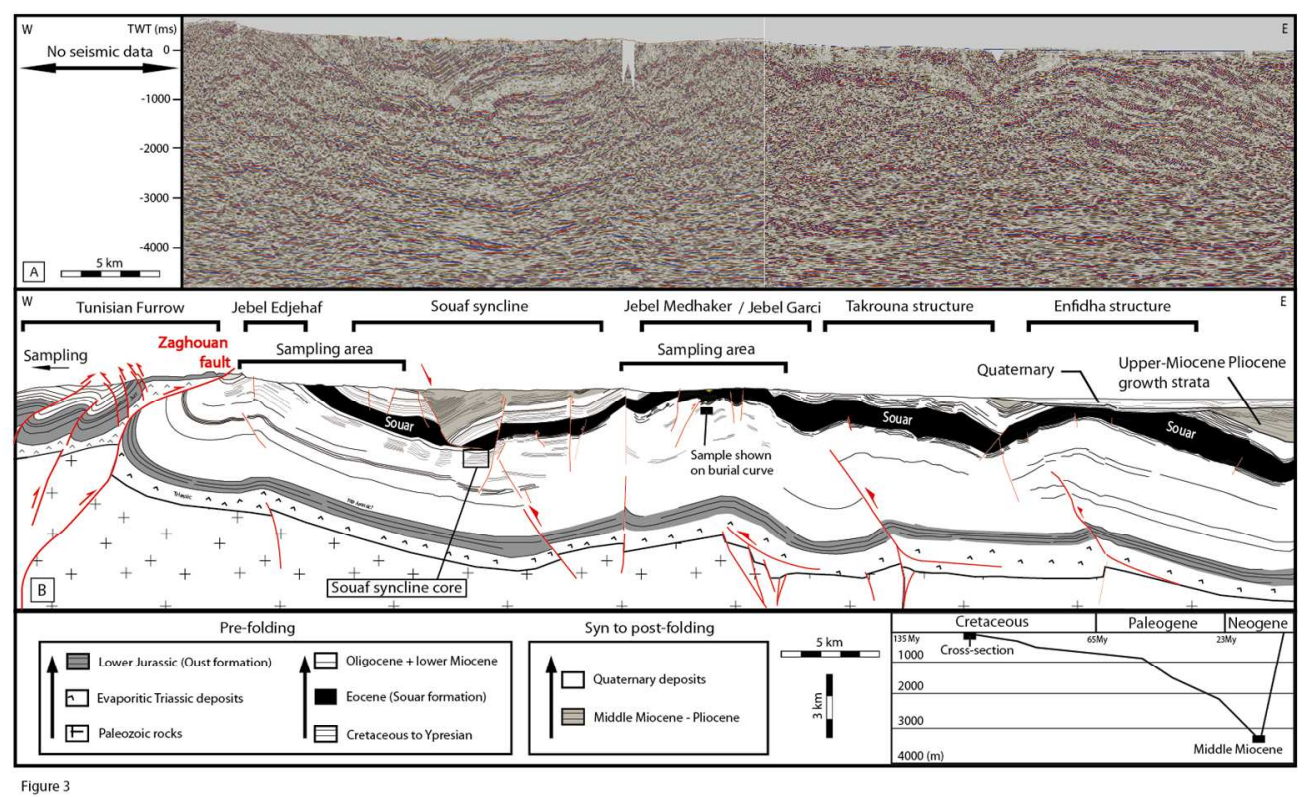

Figure 3: Sketch of the current-day geometry of the Pelagian platform near the Zaghouan fault (see E-W line location in Figure 1) based on field data and seismic profile analysis. This cross-section is nearly perpendicular to the fold trends related to the Messino-Tortonian Atlas II folding event. Qualitative burial curve is also given for Jebel Garci sampled Cretaceous rocks. 


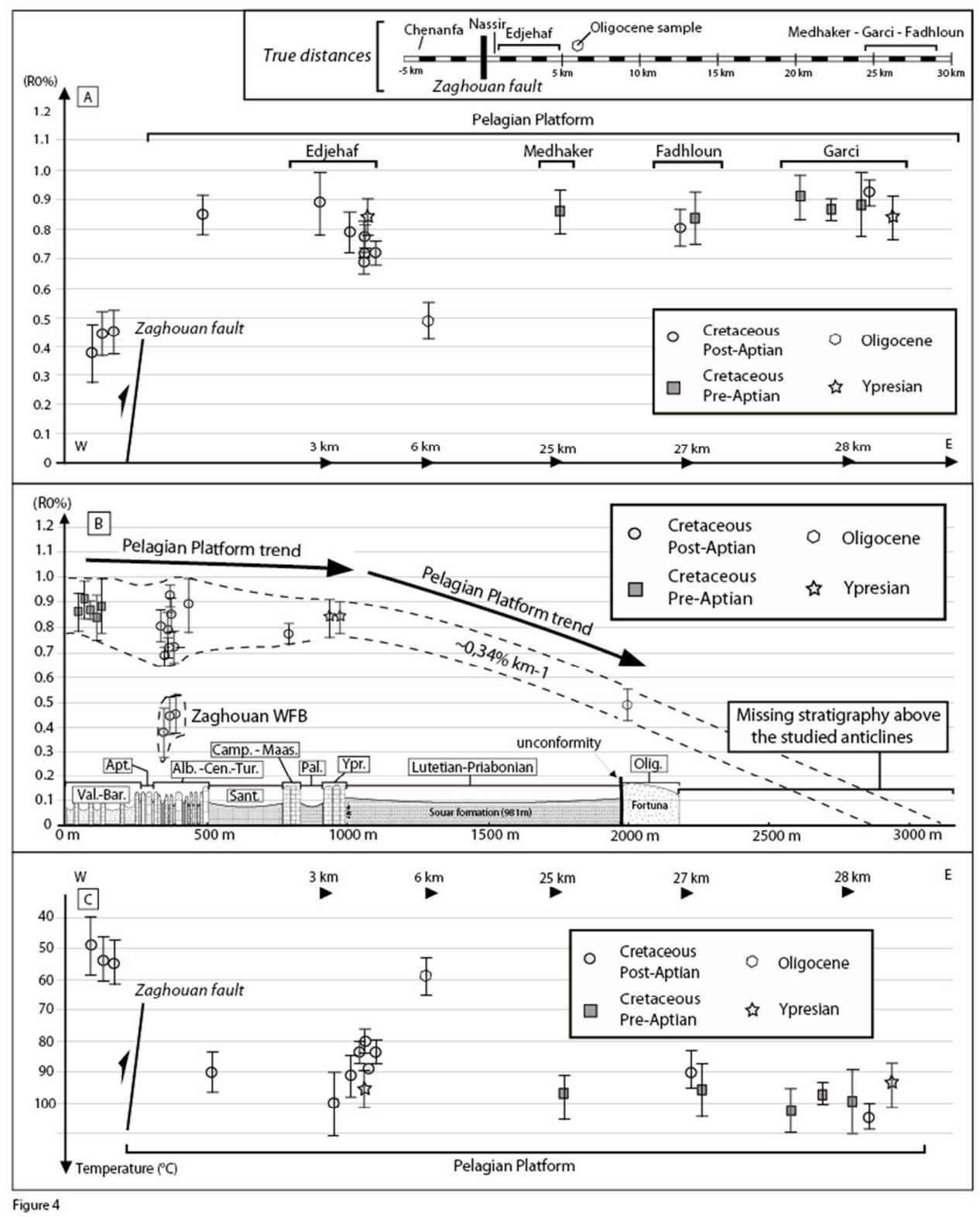

Figure 4: A) VR data plot along a West-East profile and as a function to the Zaghouan major fault distance. B) VR values as a function of formations thicknesses C) Inferred maximum temperature along a similar W-E profile based on vitrinite reflectance-temperature correlations of Vassoyevich et al. (1970) and Tobin and Claxton (2000). 
Figure 5: Inferred the maximum burial depth assuming a common geothermal gradient 0 $30^{\circ} \mathrm{C}$ per $\mathrm{km}$. $450 \times 172 \mathrm{~mm}(72 \times 72$ DPI $)$ 


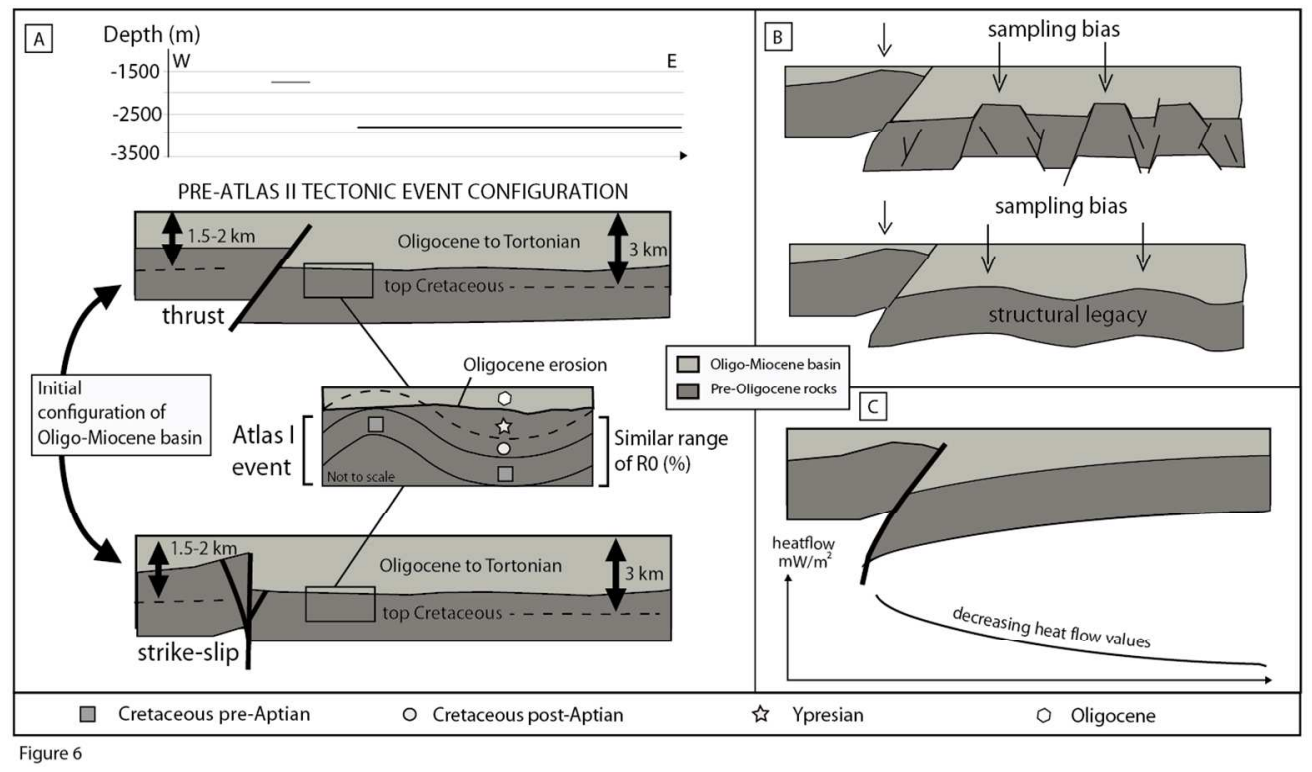

Figure 6: A) Paleo-geometry of the Pelagian platform inferred from VR data at the time of middle-upper Miocene maximum burial (Oligo-Miocene basin). These sketches highlight vertical displacement of the Zaghouan fault; note that both kinematics and fault dip is still debated. B) Sketches showing examples of sampling bias which are assumed in our interpretations. C) Sketch showing how a regional geothermal anomaly could lead to misinterpretation of VR values. Based on literature (see text for references), this latter case has been excluded of our interpretation. Dotted line shows the top of Cretaceous. Atlas II tectonic event occurred at Tortonian/Messinian times and therefore postdates the drawn configurations. 
Table 1: Age, sample location, structural domain, Zaghouan Fault Block, lithology, Kerogen type, Total Organic Content for each sample of this study. Kerogen type in bracket (III) corresponds to some terrestrial input in addition to the main type II. Vitrinite reflectance data are given with standard deviation and number of measurements. The temperature calibration is based on vitrinite reflectance-temperature correlations of Vassoyevitch et al. (1970) and Tobin and Claxton (2000).

$557 \times 240 \mathrm{~mm}(72 \times 72 \mathrm{DPI})$ 


\title{
BASIN TECTONIC HISTORY AND PALEO-PHYSIOGRAPHY OF THE PELAGIAN PLATFORM, NORTHERN TUNISIA, USING VITRINITE REFLECTANCE DATA
}

\author{
Thibault Cavailhes ${ }^{1}$, Atle Rotevatn ${ }^{2}$, Ståle Monstad ${ }^{3}$, Atef Ben Khala ${ }^{4}$, Erich Funk ${ }^{5}$, Kathryn Canner ${ }^{5}$, \\ Mirko Looser ${ }^{5}$, Ali Chalabi ${ }^{5}$, Aurélien Gay $^{6}$, Anna Travé ${ }^{7}$, Faycel Ferhi ${ }^{8}$, Ahmed Skanji ${ }^{8}$ Riadh \\ Mohamed Chebbi ${ }^{8}$ and Nils Bang ${ }^{4}$ \\ ${ }^{1}$ Université de Bordeaux (UMR EPOC - OASU CNRS 5805) Allée Geoffroy Saint-Hilaire CS 5002333615 Pessac, France, previously \\ DNO ASA \\ ${ }^{2}$ University of Bergen, Postboks 78035020 Bergen, Norway \\ ${ }^{3}$ now Point resources AS, previously DNO ASA \\ ${ }^{4}$ DNO Tunisia AS Le Tanit du Lac, Blocks C\&D Rue du Lac Windermere, Les berges du Lac Tunis 1053, Tunisia \\ ${ }^{5}$ DNO ASA, Dokkveien 1, 0250 Oslo, Norway \\ ${ }^{6}$ Géosciences Montpellier (UMR 5243), Université Montpellier 2 - CNRS; Montpellier, France \\ ${ }^{7}$ Facultat de Geologia, Universitat de Barcelona; Barcelona, Spain \\ ${ }^{8}$ ETAP, Entreprise Tunisienne d'Activités Pétrolières, 54, Avenue Mohamed V - 1002 Tunis, Tunisie \\ E-mail: thibault.cavailhes@u-bordeaux.fr
}

\section{ACKNOWLEDGEMENTS}

The authors gratefully acknowledge DNO ASA and ETAP for provision of geological data and for granting the permission to publish this paper. The authors also wish to thank Nicholas Whiteley and Abdelhak Amri for their authorization to publish this work. We thank geologists from DNO, ETAP and the University of Bergen for their contribution during fieldwork and would especially like to acknowledge Fredrik Kjelkenes, Gunnar Sælen, Bjarte Lønøy, and Jaume Vergès. We also thank Mary Ann Love Malinconico, Cara Burberry, Dominique Frizon de Lamotte and the editor of Basin Research, Rebecca Bell, for their very constructive reviews which greatly improved the manuscript.

\section{ABSTRACT}

Constraining the thermal, burial and uplift/exhumation history of sedimentary basins is crucial in the understanding of upper crustal strain evolution and also has implications for understanding the nature and timing of hydrocarbon maturation and migration. In this study, we use Vitrinite Reflectance (VR) data to elucidate the paleo-physiography and thermal history of an inverted basin in the foreland of the Atlasic orogeny in Northern Tunisia. Doing so, it is the primary aim of this study to demonstrate how VR techniques may be applied to unravel basinsubsidence/uplift history of structural domains and provide valuable insights to the kinematic evolution of sedimentary basins.

VR measurements of both the onshore Pelagian Platform and the Tunisian Furrow in Northern Tunisia are used to impose constraints on the deformation history of a long-lived structural feature in the studied region, namely the Zaghouan Fault. Previous work has shown that this fault was active as an extensional structure in Lower Jurassic to Aptian times, before subsequently being inverted during the Late Cretaceous Eocene Atlas I tectonic event and Upper Miocene Atlas II tectonic event. Quantifying and constraining this latter inversion stage, and shedding light on the roles of structural inheritance and the basin thermal history, are secondary aim of this study.

The results of this study show that the Atlas II WNW-ESE compressive event deformed both the Pelagian Platform and the Tunisian Furrow during Messinian-Tortonian time. Maximum burial depth for the Pelagian Platform was reached during Middle to Upper Miocene, i.e. prior to the Atlas II folding event. VR measurements indicate that the Cretaceous to Ypresian section of the Pelagian Platform was buried to a maximum burial depth of $\sim 3 \mathrm{~km}$, using a geothermal gradient of $30^{\circ} \mathrm{C} / \mathrm{km}$. Cretaceous rock samples VR values show that the hanging wall of the Zaghouan Fault was buried to a maximum depth of less than $2 \mathrm{~km}$. This suggests that a vertical $\mathrm{km}$-scale throw along the Zaghouan Fault pre-dated the Atlas II shortening, and also proves that the fault controlled the subsidence of the Pelagian Platform during the Oligo-Miocene. Mean exhumation rates of the Pelagian Platform throughout the Messinian to Quaternary were in the order of $0.3 \mathrm{~mm} / \mathrm{y}$. However, when the additional 
effect of Messinian-Tortonian folding is accounted for, exhumation rates could have reached 0.6-0.7 $\mathrm{mm} / \mathrm{y}$.

Key words: inverted structures, tectonics, Atlas, oil

\section{INTRODUCTION}

Understanding the thermal, burial and exhumation histories within sedimentary basins is essential for a range of fundamental and applied purposes (O'hara et al., 1990; Laughland \& Underwood, 1993; Mazurek et al., 2006; Yuan et al., 2007; Sakaguchi et al., 2007). Such understanding is critical to elucidate the geodynamic context and history of sedimentary basins, and is applicable to hydrocarbon source rock evaluation in which the prediction of subsurface organic matter maturity distribution remains a key issue for basin modeling (Malhlmann and Le Bayon, 2016). In this study, we use structural and vitrinite reflectance (VR) data to investigate the complicated thermal, burial and exhumation history of a tectonically polyphase sedimentary basin, in order to elucidate its geodynamic evolution in a regional context, the current-day Atlas Eastern foreland.

The thermal histories of foreland basins record the regional tectonic evolution of peripheral parts of orogens through space and time; understanding the tectonothermal history of a foreland basin may therefore also shed light on the tectonic evolution of the entire orogen (Allen and Allen, 2005). Influence of pre-existing structural fabrics is well known in orogens (Audet \& Burgmann, 2011; Butler et al., 2006), and inherited extensional structures that have been reactivated during later events of compression may significantly control locations of geologic subsidence (Thomas, 2004, Allen and Allen, 2005, Panien et al., 2005; Bonini et al., 2012 for review; Guiraud \& Bosworth, 1997 for Atlas). Since the thermal history is a function of subsidence (and exhumation) and the geothermal gradient, investigating the spatial variations in thermal history may shed light on where/how subsidence was accommodated, and whether pre-existing structural fabric were exploited.

In this contribution, we investigate the thermal evolution of the folded Pelagian Platform in the Enfidha region (Northern Tunisia), which was deposited during Mesozoic and early Cenozoic times, and deformed during both Eocene Atlas I and Upper Miocene Atlas II tectonic events (Khomsi et al., 2009). We do this in an attempt to unravel the tectonic history of structural domains, and the role of pre-existing extensional structures to accommodate shortening related to Atlas tectonic phases (Guiraud \& Bosworth, 1997). In doing so, we provide an example were VR and structural data are used to investigate thermal history of sedimentary succession through space, which in turn is used to decipher the burial/uplift spatiotemporal evolutions of two distinct structural domains

Although previous studies have shed light on the kinematic history, structural style and depositional evolution of the basin (e.g. Khomsi et al., 2006, 2009; Morgan et al., 1998; Bouaziz et al., 2002), the thermal evolution of the Pelagian Platform, currently located to the east of the Tunisian Atlas, and its tectonic relation to the Tunisian Furrow remains poorly understood.

The specific main goal of this study is to elucidate/quantify the tectonothermal, burial and exhumation history of two distinct structural domains separated by a major polyphase structural feature, using structural data and VR data. This is done through focusing on the case of the the Zaghouan-Ressas structural belt (Morgan et al., 1998) of the Pelagian Platform in Northern Tunisia, and we address this main goal through the following set of specific objectives: (i) elucidate the role of structural inheritance in the evolution of the Pelagian Platform basin in the Atlas foreland; (ii) assess the maximum temperature reached by the studied succession; (iii) quantify the differential burial history of two main structural domains in the studied area (Hezzi, 2014); and ultimately (iv) quantify their exhumation rates.

\section{GEOLOGIC SETTING}

The Tunisian Atlas consists of intra-continental fold and thrust belts that mainly result of the collision between Africa and Eurasia in two distinct episodes of convergence, a Middle-Late Eocene one and a Miocene-Pliocene one (Frizon de Lamotte et al., 2009). The study area is located in the 
Enfidha region of Northern Tunisia where two structural domains coexist, the Tunisian Furrow and the Pelagian Platform (Fig.1). The Pelagian Platform forms part of the Pelagian Province that extends offshore into shelf area of northern Libya and east-central Tunisia, and northwards towards Malta (Klett, 2001). The western boundary of the Pelagian Platform is located onshore Tunisia, along the socalled 'North-South axis' (Fig. 1; Ben Ayed and Viguier, 1981). Within the studied area, the NorthSouth axis is expressed by the Zaghouan fault, which in Jurassic times was an extensional structure that controlled the location of the eastern margin of a marine carbonate platform; the Zaghouan Fault delineated the 'Tunisian Furrow' structural domain where this carbonate platform was located (Ben Ayed and Viguier, 1981; Chihi, 1985; Saadi, 1990; Melki et al., 2010 \& 2011; Hezzi, 2014, Fig.1A). This Mesozoic margin is characterized by N-S to SW-NE trending grabens that formed related to EW/NW-SE polyphase extension, crustal thinning and subsidence; these grabens accommodated synrift successions of Lower Jurassic to Aptian marls and carbonates (Morgan et al., 1998; Fig.1B). The geometry at depth of the Zaghouan Fault, and its role in later tectonic events and the development of the Zaghouan-Ressas structural belt is, however, debated (Hezzi, 2014).

Previous work has shown that the following deformation events have subsequently affected the study area: (i) Compressive deformation began by the Santonian and is followed by a Paleocene period of relative quiescence (Laffite, 1939). (ii) Evidence for episodic Atlas I transpressive deformation, thrust faulting and folding is recorded during middle/late Eocene (Khomsi et al., 2009). This Eocene-aged event related to Atlas I phase has triggered local uplift, imposed a probable structural control on basin geometry, influenced the local sedimentation patterns and ultimately caused reverse reactivation of the Zaghouan Fault in the study area (Burollet, 1967; Guiraud, 1998; Morgan et al., 1998; Khomsi et al., 2009). The Atlas I contractional phase is also characterized by angular unconformities of middle Eocene age identified on the flanks of anticlines from 2D reflection seismic sections and sealed by a pre-Oligocene unconformity (Khomsi et al., 2006; Frizon de Lamotte et al., 2006). (iii) A period of relative tectonic quiescence characterized the Oligocene-early Miocene, with only minor extension taking place (Khomsi et al. 2009) and the development of associated isolated extensional structures. In particular, a Lower to Middle Miocene transtensional phase is expressed by W-NW to E-SE striking faults in the studied area (Philip et al., 1986). The Flexure in the South Eastern frontal region of the Intermediate Atlas, and the onset of incipient extension in the PantelleriaLinosa-Malta Rift System were the dominant factors controlling the Oligo-Miocene development of the study area (Khomsi et al., 2009; Frizon de Lamotte et al., 2009). (iv) The most significant event recorded in the studied region is the second phase of Atlas shortening, called the Atlas II event, which affected both the Pelagian Platform and the Tunisian Furrow in Tortonian to Messinian times (Castany, 1951; Richert, 1971; Rouvier, 1977 ; Philip et al., 1986; Khomsi et al., 2009; Fig.1 and 3). (v) A Pliocene to Villafranchian episode of transtensional deformation partly overprinted the contractional structures (Philip et al., 1986), and led to the formation of W-NW to E-SE striking normal faults. This transtensional event is likely related to the final stage of the Pantelleria-LinosaMalta Rift System in Plio-Quaternary times (Frizon de Lamotte et al., 2009).

In addition to the mentioned series of tectonic events, halokinesis is thought to have been active from Jurassic to early Eocene times in Eastern Tunisia (Mejri et al., 2006). Brahim and Mercier, (2007) as well as Rigane and Gourmelen, (2011) have proposed that middle Eocene unconformities of the Pelagian Platform can locally result from progressive salt diapirism within the studied region. However, Pre-Oligocene unconformity has been recognized in the whole Magreb and thereby cannot be only explained by local diapirism (Frizon de Lamotte et al., 2009).

A mechanically layered stratigraphy, with weak evaporitic horizons separating more competent rocks, may therefore have exerted strong controls on the structural style of the study area throughout its tectonic history outlined above. Related to this, Morgan et al. (1998) proposed two models for the structural evolution of the Zaghouan-Ressas structural belt (ZRSB): (i) the ZRSB developed as a results of thin-skinned Miocene contractional deformation expressed as thrusting localized onto detachments within a Triassic evaporitic interval (Baird et al. 1990; Anderson 1991, 1996; Outanni et al. 1995); this model assumes that the deformation of both Pelagian Platform and ZRSB was largely thin-skinned, with no or minor involvement of the Zaghouan Fault; or (ii) the ZRSB developed as a result of thick-skinned deformation and inversion of pre-existing extensional basement faults; this model implies that, in the studied area, the Zaghouan Fault was reactivated and inverted since Paleocene times (Morgan et al., 1998). 


\section{METHOD AND SAMPLING STRATEGY}

166

167

168

169

170

171

172

173

174

175

176

177

178

179

180

181

182

183

184

185

186

187

188

189

190

191

192

193

194

195

196

197

198

199

200

201

202

203

204

205

206

207

208

209

210

211

212

213

214

215

216

217

\section{VR, temperature and burial}

Vitrinite is one of the primary components of coals, representing organic compounds derived from 'gel' ligno-cellulosic debris (Baudin et al., 2008). The reflectance of vitrinite, (vitrinite reflectance -VR), is commonly used to constrain the thermal maturity of both coal and hydrocarbon source rocks in the range of late diagenesis to very low grade metamorphism. i.e. $40^{\circ} \mathrm{C}$ to $320^{\circ} \mathrm{C}$, Kubler \& Jaboyedoff, 2000; Arkai et al., 2007; Baudin et al., 2008). An increase of VR with depth is commonly observed in borehole profiles, as predicted by 'Hilt's Law', and is caused by increasing temperature with depth (Stach et al., 1982). Therefore, accurate field observations and related rock sampling allow for a reliable determination of thermal history, and by inference, burial history, based on VR data (e.g. O'hara et al., 1990; Cavailhes et al., 2013; Green et al., 2016).

\section{Strategy to unravel basin paleo-geometry}

VR data can be used to quantitatively describe paleo-basin physiography near major faults, such as the Zaghouan Fault. The paleo-basin geometry can be inferred by combining the information about the thermal history extracted using the VR method and related samples structural locations, particularly in cases where deformation events post-date the time of maximum burial (see results for maximum burial time, in "Structure" section). Figure 2A displays a simplified and conceptual crosssection of the present-day structure in order to highlight our strategy; In Figures $2 \mathrm{~B}$ through $2 \mathrm{~F}$, five alternative hypotheses for the pre-folding geometry of the study area; the sampling strategy was designed to test these competing hypotheses. Figure $2 \mathrm{~B}$ shows a hypothetical scenario of a preexisting normal fault dipping to the west and burial of the western block deeper than the eastern block (hanging-wall). The hypothesis illustrated in Figure $2 \mathrm{C}$ is similar to the case in Figure 2B with the exception of an eastward dip of hanging-wall strata. An alternative with an overall westwards tilt of the basin, and where stratal thickening is not influenced by the fault, is shown in Figure 2D. Figure 2E shows an alternative hypothesis, where the western block can be interpreted as a paleo-high, whilst the eastern block (footwall) is west-ward tilted due to major reverse fault kinematics i.e. with the maximum subsidence being located in the footwall, at the vicinity of the thrust. Figure $2 \mathrm{~F}$ shows a similar case to Figure 2E, yet in this model the basin does not display any regional tilting of the eastern footwall block. All five hypothetical paleo-basin geometry scenarios are assumed to be at the time- of maximum burial.

\section{Sample analytical procedure}

Samples of limestone and sandstone containing organic matter were analyzed as shown in Table 1. The samples were crushed, set in a cold epoxy resin block, ground and polished. VR determination was performed in a dark-room using a Zeiss Standard Universal research microscopephotometer system (MPM01K) equipped with a tungsten-halogen lamp, a 40X Epiplan oil immersion objective, filtered $546 \mathrm{~nm}$ incident light and Zeiss immersion oil (ne 1.517@23 ${ }^{\circ} \mathrm{C}$ ). The applied method is consistent with the guidelines stated in the International Organization for Standardization publications ISO 7404-2, ISO 7404-3 and ISO 7404-5. Analysis have been performed in Intertek Sunbury Technology Centre of the Petroleum Geochemistry company.

\section{Sample locations and derived ages}

In order to test the competing hypotheses shown in Figure 2, twenty representative rock samples with significant TOC content along an E-W transect across the studied area were selected for VR analysis (Fig. 1). The sampling transect is oriented perpendicular to the main N040 fold axes (Fig.3). Sampling locations include: Jebel Edjehaf, Jebel Garci, Jebel Medhaker, Jebel Fadhloun, Jebel Nassir (east of the Zaghouan Fault) and Chenanfa, (west of the Zaghouan Fault; Fig.1 and Table 1). The 20 high-TOC samples cover the following ages and subages: Valanginian/Barremian- (1 sample); Barremian (4 samples); Bedoulian (1 sample); Albian (2 samples); Vraconian (3 samples); Cenomanian-Turonian (5 samples); Campanian (1 sample); Ypresian (2 samples) and Oligocene (1 sample) (see right part of Figure 1). All samples are marine carbonate samples except the fluvio- 
deltaic Oligocene sandstones. The samples were mostly selected from structural highs where relatively older rocks were exposed (crest of anticlines or reverse-fault hanging-wall). However, this strategy does introduce a sample bias that is discussed later in this paper.

\section{RESULTS}

\section{Structure}

Figure 3 shows a W-E structural cross-section that has been constructed using (1) outcrop data, (2) satellite imagery and (3) proprietary 2D seismic data. The seismic data was calibrated against outcrop and well log data, and a burial curve of Jebel Garci (see figure 1 for location) has been constructed based on known stratal thicknesses and related ages (Fig. 3).

From west to east, four main N-NE trending anticlines affecting the Pelagian Platform succession were mapped by the authors. They are all open folds of km-scale-width and are termed, from west to east: Jebel Edjehaf, Jebel Garci, the Takrouna structure, and the Enfidha structure. Both Jebel Medhaker (to the North) and Jebel Fadhloun (to the south) anticlines are structurally equivalent to Jebel Garci anticline. The Pelagian Platform succession in the Jebel Edjehaf anticline, which is $2 \mathrm{~km}$ to the east of the Zaghouan fault, is $5 \mathrm{~km}$ wide, $20 \mathrm{~km}$ long and exhibits the tightest fold. The $20 \mathrm{~km}$ wide Souaf separates the Jebel Edjehaf and Jebel Garci anticlines (Fig. 3); the upper Miocene section of the Souaf Syncline is folded, and the whole syncline is dissected by a N110 transversal graben (i.e. perpendicular to the fold) with Pliocene and Quaternary age infill (Fig.3). The Jebel Garci anticline, located in the eastern part of the Pelagian Platform, is c. $5 \mathrm{~km}$ wide and $8 \mathrm{~km}$ long, i.e. significantly less elongated than the Jebel Edjehaf. A tight syncline separates Jebel Garci and the Takrouna structure, the latter of which is a $5 \mathrm{~km}$ wide anticline expressed at the surface in Oligocene age stratigraphy. Further east, the Enfidha structure is buried below Quaternary deposits but is recognized in both seismic profiles and borehole data (Fig.3). Syn-kinematic 'growth' strata, indicate thinning across fold limbs in the Mio-Pliocene succession.

Based on the interpretation shown in Figure 3, shortening of the Pelagian Platform from the Zaghouan fault to the coastline along an ESE-NNW direction is estimated to be in the range of $9 \%$ to $12 \%$ i.e. between 5 and $8 \mathrm{~km}$ (Fig.3). VR study may also narrow the relative timing of the shortening and the amount of subsequent erosion.

\section{VR data}

The VR samples are described as a function of their age and structural location relative to the Zaghouan Fault (Zaghouan western fault block, WFB, or Zaghouan eastern fault block, EFB; see Figure 3 for cross-section, Figure 2 for sample transect and Table 1 for VR values). The three Cretaceous samples from the WFB show values between $0.38-0.46 \%$ for reflectance (Fig.4A). All samples from the EFB (i.e. the Pelagian Platform) range from 0.5 to $0.95 \%$. The Cretaceous samples from the WFB thus exhibit approximately 50\% lower reflectance values compared to those of the EFB.

The Oligocene sample from the EFB represents the lowest reflectance value of the dataset (c. $0.5 \%$ ), which is consistent with the youngest stratigraphic age of the sampled succession. The Ypresian carbonate rocks of the Jebel Garci and Jebel Edjehaf anticlines (also EFB) show VR of $0.85 \%$, and are therefore in a similar range to the Cretaceous samples of the EFB.

The Cretaceous pre-Aptian samples from the Jebel Medhaker, Jebel Fadhloun and Jebel Garci within the EFB exhibit reflectance values ranging from 0.85 to $0.95 \%$ (Fig.4A); pre-Aptian age rocks are not exposed at Jebel Edjehaf (Fig.3).

The post-Aptian rocks of the EFB, excluding the Oligocene sample, have values ranging from $0.7 \%$ to $0.9 \%$ in Jebel Edjehaf, c. $0.8 \%$ in Jebel Fadhloun and c. $0.9 \%$ in Jebel Garci.

The graph of the Figure 4B shows the VR values as a function of formation thicknesses for the entire study area. No distinction has been made between the different studied anticlines. The VR values of WFB are significantly lower $(\sim 0,5 \%)$ than the ones from the Pelagian Platform (EFB) for a 
similar upper Cretaceous interval. All pre-Ypresian samples of the Pelagian Platform are in a similar VR values range and, surprisingly, do not show any VR decrease in relation with the youngest age of those Pre-Ypresian formations. In contrast, a decrease of VR values clearly appears from the Ypresian samples to the Oligocene sample, where Lutetian-Priabonian Souar clays are present. Graphically, the average slope value is here around $-0.34 \% \mathrm{~km}^{-1}$, assuming that the Souar formation is $981 \mathrm{~m}$-thick. However, due to the sampling gap, we do not know the exact location of the slope break in this stratigraphic interval (Fig.4B).

\section{Temperature calibration}

The measured VR value is a function of many parameters, including temperature, time, original oxygen content, pore fluid pressure, fluid chemistry, oil content, type of organic content, $\mathrm{CH}_{4}$ presence, partial $\mathrm{CO}_{2}$ pressure, degree of tectonic deformation of the sample, oxidation and weathering (Hood et al., 1975; Waples, 1980; Price, 1983; Barker \& Pawlewicz, 1986; Huang, 1996). However, Huang, (1996) demonstrates that the main controlling parameter of the VR is the maximum temperature reached by the rock through its geological history. In the last four decades, different methods have been used to calibrate the VR with the maximum temperature that rocks were exposed to (e.g. Vassoyevich, 1970; Sweeney \& Burnham, 1990, Tobin \& Claxton, 2000; Barker \& Pawlewitcz, 1994; Arkai et al., 2007). In this study, thermal calibration following Vassoyevich et al. (1970) and Tobin and Claxton (2000) have been used. The latter method involves calibration by other thermometers such as fluid inclusions and illite crystallinity index.

The calibrated VR values indicate that (Fig. 4B) (i) the post-Aptian rocks from the WFB reached maximum temperatures of around $55^{\circ} \mathrm{C}$; (ii) the Oligocene sample from the Pelagian Platform (EFB) reached a temperature of approximately $60^{\circ} \mathrm{C}$; (iii) pre-Aptian rocks of the Jebel Medhaker, Jebel Fadhloun and Jebel Garci anticlines (all EFB) reached temperatures of approximately $100^{\circ} \mathrm{C}$; (iv) the post-Aptian rocks in the Pelagian Platform (EFB) recorded temperatures in the range of $80^{\circ} \mathrm{C}$ to $105^{\circ} \mathrm{C}$, with a mean of $85-90^{\circ} \mathrm{C}$ for Jebel Edjehaf and Jebel Fadhloun.

Summarized, the temperatures reached in the WFB are significantly lower than the measurements from similar cretaceous stratigraphic intervals in the EFB.

\section{DISCUSSION}

In this the following discussion we show how the presented VR (Fig.4 and 5) and structural data can be used to decipher foreland basin history in an area where a long-lived pre-existing structure (the Zaghouan Fault) affected deformation and basin subsidence (Fig.6).

\section{Temperature}

The combination of structural studies and VR analysis across the Pelagian Platform has revealed that the maximum temperatures that were reached by Cretaceous rocks in the study area were between $80^{\circ} \mathrm{C}$ and $100^{\circ} \mathrm{C}$ (Fig.4). The Jebel Garci values show similar order of magnitude of VR as the other Cretaceous samples from the Pelagian Platform. Conversely, the Cretaceous samples from the Zaghouan WFB reached temperatures of approximately $55^{\circ} \mathrm{C}$.

Regional trends of VR do not show an increase westward toward the present-day thrust belt, therefore confirming that the thrust location did not have any influence on footwall rock maturation (Fig.4). This is consistent with published work highlighting that no regional thermal diagenesis/metamorphism can be attributed to fault-generated heat, with the exception of very narrow (cm-scale) films immediately adjacent to the fault slip surface (Bustin, 1983; Suchy et al., 1997; Sakaguchi et al., 2007), heating processes mostly resulting from frictional heating (Scholz, 1980) or heating related to hydrothermal fluids within the fault zone (Guilhaumau \& Dumas, 2005). The particular case of Figure $6 \mathrm{C}$, where the heat flow is sketched as regionally increasing towards the fault, is thus excluded for this study.

\section{Maximum burial depth}

In order to infer the maximum burial depth using maximum temperatures, it is necessary to estimate/assume a geothermal gradient. This can be estimated using (i) published data considering a 
regional geological context (e.g. Ben Dhia, 1987 for Tunisia, Labaume et al., 2008 for the Alps), and (ii) using present-day geothermal gradients inferred from wellbore temperature data; the latter assumes consistency between current-day thermal heat flow and paleo thermal heat-flow at the time of maximum burial depth. Values in offshore wells range from about $3.5^{\circ}$ to $4.5^{\circ} \mathrm{C} / 100 \mathrm{~m}$ (Lucazeau and Ben Dhia, 1989), higher than published values from onshore wells (Compagnie des Pétroles de Tunisie, 1955). Based on the Jebel Edjehaf well data (Compagnie des Pétroles de Tunisie, 1955), and values from the published literature for the peripheral part of the orogeny (Yuan et al., 2007; Labaume et al., 2008; Metcalf et al., 2009; Cavailhes et al., 2013), we assume a paleo-geothermal gradient of $30^{\circ} \mathrm{C} / \mathrm{km}$ for this study.

Based on this assumption, our results suggest that the Pelagian Platform has been uniformly buried to a minimum burial depth of $3 \mathrm{~km}$ (+ or $-500 \mathrm{~m}$ ) (Fig.5). This burial for Pre-Ypresian samples agrees with overburden sediment thickness estimates, based on seismic profile analysis from the core of the Souaf Syncline, also located in the Pelagian Platform (Fig.3). The Oligocene sample was buried at a shallower depth $(2 \mathrm{~km})$ than the Pre-Ypresian samples $(3-3.5 \mathrm{~km})$, despite the fact that they are in an equivalent structural position and elevation along the sampling profile, i.e. comparable elevation along the present-day topography crossing the fold. This clearly confirms that the current-day observed fold shape has been mainly acquired after the Miocene maximum burial of studied rocks i.e. during the Atlas II tectonic event.

The observed differences in burial depth $(\sim 1 \mathrm{~km}$, Fig.5) between the Ypresian and Oligocene samples of the Pelagian Platform may be explained by (i) the principles of "Hilt's Law", i.e. decrease of VR towards surface (Stach et al., 1982); (ii) the Oligocene erosion that occurred subsequently to Atlas I event and probably having removed materials (Frizon de Lamotte et al., 2009); or (iii) the probable thermal effects and related thermal compartmentalization caused by relatively low thermal conductivity of the Eocene $981 \mathrm{~m}$-thick clay succession of the Souar Formation (Fig.4B). Indeed, clays have commonly lower thermal conductivity than carbonates (Eppelbaum et al., 2017).

Based the cross-section of Figure 3, we propose that interpretation (i) and (iii) are the most probable. Indeed, according to the previously cited literature (e.g. Khomsi et al., 2009) and this study, no significant burial history occurred subsequent to the Messinian-Tortonian Atlas II folding phase. Moreover, $2 \mathrm{~km}$ of additional burial for Oligocene samples is needed if hypothesis (ii) is to be verified (Fig. 5).

Regarding the Zaghouan WFB, VR values show that the Cretaceous rocks have been maximally buried at a depth of $1.5-2 \mathrm{~km}$ (Fig.5). This study, and related depth calibration, therefore suggest a strong contrast in burial depth between the fault blocks on either side of the Zaghouan Fault; therefore, a km-scale vertical displacement of the Zaghouan fault at the time of maximum burial is deduced (Fig.6A). The inherited Zaghouan Fault has been widely described as an inverted normal fault/transpressive strike-slip structure (e.g. Hezzi, 2014 and references therein; Guilhaumau \& Dumas, 2005). Consequently, we propose two plausible schematic cross-sections to illustrate the Paleogene kinematics of the Zaghouan Fault and its current-day observed displacement (Fig.6A). The Oligo-Middle-Miocene basin in its Pre-Atlas II tectonic event configuration was therefore bounded by the Zaghouan fault in its eastern part, which was either an inverted normal fault or a strike slip system; in both cases, the Pelagian Platform was subsiding (Fig.6A).

The increase in VR between the Pelagian Platform and a similar stratigraphic interval of the Zaghouan WFB can be attributed to the increased thickness of deposited sediments. Depth calibrations show that the Pelagian Platform samples were uniformly buried to similar burial depths (Fig. 5). This suggests that the Zaghouan Fault did not trigger wide-scale-block-tilting between the Atlas I and Atlas II tectonic episodes, and thus excludes asymmetric paleo-geometries for the Pelagian Platform; the hypotheses which are shown in Figure 2 B, C, D and E are therefore ruled out. The Pelagian Platform was not buried more deeply near the Zaghouan fault, in contrast to what is found in some other peripheral parts of orogens or foreland basins (Bonini et al., 2012). The configuration of Figure $2 \mathrm{~F}$ is therefore the most probable one and is detailed in Figure 6.

Probable paleo-topographies and pre-existing structures may have existed and related subsiding points have not been sampled due to vitrinite sampling bias (data are available for only outcropping rocks; Fig.6B). The methodology assumes that both the maximum burial depths within the E-W graben and the hearts of the synclines are slightly higher than what is recorded for the 
outcropping anticlines of the area (Fig. 6B). It is likely that the data does give an under-estimation of burial depth for these present-day buried structures.

All Cretaceous and Ypresian samples show similar ranges of VR values $(\sim 0.9 \%)$, meaning that maximum burial depth was reached during post-Ypresian time. Consistent with Khomsi et al., (2009), it is improbable that maximum burial occurred during the middle-late Eocene, i.e. during the positive tectonic inversion related to the Atlas I contraction. Our structural data and burial curve do suggest that maximum burial was established prior to the Tortonian-Messinian Atlas II folding phase (Fig.3). This inference is consistent with previous work arguing for a negative inversion (i.e. transtensional phase) recorded during the Oligocene-Middle Miocene (Philip et al., 1986; Morgan et al. 1998; Khomsi et al., 2009; Fig.6A). Additionally, constant VR values all over the Pelagian Platform for all pre-Ypresian stratigraphic intervals supports the interpretation that a pre-Oligocene folding (Atlas I event) followed by erosion probably put all the samples at a same level before the Oligo-Miocene subsidence (Fig.6A). This Oligocene unconformity (post Atlas I event) may therefore localize the VR values slope break that has not been clearly characterized on the Figure 4B stratigraphic column (only average slope value has been proposed).

During the time of maximum burial depth for the Pelagian platform, the Zaghouan fault was important as it appears that the Zaghouan WFB (i.e.Tunisian Furrow) was buried at a maximum depth of less than $2 \mathrm{~km}$ below the surface while the Pelagian platform was buried between 3 and $3.5 \mathrm{~km}$. According to these burial values, the cumulative vertical displacement along the Zaghouan Fault was at least $1 \mathrm{~km}$ during the pre-folding Atlas II episode in middle to late Miocene times. Having therefore cumulated a significant vertical throw, the Zaghouan fault was already increasing the subsidence of the Pelagian Platform. Consistent with the burial curve shown in Figure 3, this km-vertical throw has most likely been accrued throughout the various tectonic phases, including Paleocene/Eocene Atlas I shortening phases (Khomsi et al., 2009; Frizon de Lamotte et al., 2009); the Oligocene - middle Miocene negative inversion (Philip et al., 1986; Morgan et al. 1998; Khomsi et al., 2009), and the contractional deformation (thrusting) along the Zaghouan Fault, the latter probably predating the peak of the Tortonian-Messinian Atlas II event in the foreland studied area (this study). Most of the subsidence has been acquired during the establishment of the Oligo-Miocene basin predating the Atlas II tectonic event as sketched on the Figure 6A.

Regarding the Pliocene to Villafranchian transtensional deformation giving the second main structural overprint of the studied area (Philip et al., 1986), our VR data does not show any clear N-S control of reflectance values (From the North to the South, respectively: Jebel Medhaker, Jebel Garci, Jebel Fahdloun are on a similar structural trend), suggesting that this phase of deformation did not contribute to any significant extent to the burial of the studied area/interval.

\section{Exhumation rates}

Using the above structural and thermal data, this study suggests that the Pelagian Platform was buried to nearly $3.5 \mathrm{~km}$ (Fig.5), implying that an equivalent magnitude of overburden has since been removed by erosion. Knowing the maximum burial depth of the Pelagian Platform Pre-Ypresian carbonates allows the computation of the average exhumation rates for the study area, by assuming a structural evolution of the succession and its present day surface exposure in the study area.

The onset of the exhumation is most likely triggered by the Atlas II (Tortonian) contractional event. For an exhumation that has been lasting from the Tortonian to the Quaternary (Philip et al., 1986), the mean exhumation rates for the Edjehaf, Medhaker, Fadloun, and Garci anticline structures would need to be in the order of $0.27 \mathrm{~mm}$ and $0.32 \mathrm{~mm} /$ year (i.e. $3 \mathrm{~km}-3.5 \mathrm{~km}$ over $11 \mathrm{Ma}$ ) to reach the sampled current-day outcropping position. Assuming the extreme case that the exhumation of the Pelagian Platform could be exclusively related to the Atlas II Folding Event (Tortonian to Messinian), exhumation rates for the aforementioned anticline structures can reach values of up to $0.6-0.7 \mathrm{~mm} / \mathrm{year}$ (i.e. $3 \mathrm{~km}-3.5 \mathrm{~km}$ over $5 \mathrm{Ma}$ ). The estimated exhumation rate derived for the heart of the Souaf Syncline is around $0 \mathrm{~mm} /$ year (negligible, no exhumation), owing to the fact that the maximum burial depth reached by the studied rocks (VR data) is consistent with the current-day depth computed from our structural cross-sections. However, as already discussed above, maximum burial depths reached by the rocks in the heart of the syncline may have been underestimated (because of no sampling), implying that exhumation rates are also underestimated. 


\section{SUMMARY AND CONCLUSIONS}

Vitrinite reflectance (VR) is a valuable tool to quantitatively document differential burial histories commonly seen in fault controlled sedimentary basins and basin segments that have undergone multiple tectonic events. We used VR analysis to unravel the tectonic history of the Pelagian Platform and the Tunisian Furrow in Northern Tunisia. The following main conclusions are drawn:

1) Based on our seismic/field data and consistently with the literature, the contractional event related to the Atlas II WNW-ESE compressive phase deformed both the Pelagian Platform (folds) and the Tunisian Furrow during Tortonian to Messinian time

2) Maximum burial depth of Pre-Miocene rocks of the Pelagian Platform was reached during middle to upper Miocene times i.e. prior to the Atlas II olding event.

3) Cretaceous to Ypresian carbonates of the Pelagian Platform were buried to a maximum burial depth of approximately $3 \mathrm{~km}$, assuming a geothermal gradient of $30^{\circ} \mathrm{C} / \mathrm{km}$.

4) Cretaceous rock samples from the hanging wall of the Zaghouan Fault (current-day Zaghouan WFB) were buried to a maximum depth of less than $2 \mathrm{~km}$.

5) Significant throw along the Zaghouan fault pre-dates the Atlas II Miocene folding event and has controlled subsidence of the Pelagian Platform during the Tertiary.

6) The Zaghouan fault did not trigger any regional-scale block-tilting during the Tertiary, assuming a sampling bias that is discussed in this study.

7) Based on maximum burial depth and its Miocene timing, mean exhumation rates of the Pelagian Platform during the Messinian to Quaternary averaged around $0.3 \mathrm{~mm} / \mathrm{y}$. However, once the Tortonian -Messinian Atlas II folding event is taken into consideration, exhumation rates could have reached orders of magnitude of up to $0.6-0.7 \mathrm{~mm} / \mathrm{y}$.

These conclusions do provide quantitative constraints on the tectonic evolution of Northern Tunisia and have important implications on the timing of hydrocarbon maturation and expulsion, particularly for the Mesozoic and early Tertiary source rock intervals deposited in the Pelagian Platform region. More generally, providing burial data and exhumation rates with respect to structural data are critical inputs for numerical basin modeling and therefore enable petroleum geoscientists to accurately assess source rock maturation such as time-scale for fluid transfer throughout sedimentary basins.

\section{FIGURE CAPTION}

Figure 1: A) Structural sketch of the Enfidha region in Northern Tunisia (see inset map for location) showing toponymy, geologic structures, and ages of strata. The structural sketch has been modified from Turki (1985). The location of the cross-section of Figure 3 is shown. B) Simplified stratigraphy of the studied area with the stratigraphic locations of VR samples (square, circle, star, octagon; see also key in Figure 4 and 5). AT.I = Atlas I tectonic event, AT.II = Atlas II tectonic event. Samples details are given in Table 1. Formation thicknesses and stratigraphic sample locations are also given in Figure 4B.

Figure 2: A) Present-day conceptual cross-section of the studied area. Main black fault is the Zaghouan fault. B), C), D), E, F) are hypothetical pre-folding geometries that can be tested using VR 
data. Indicative VR trend is given for each sketch in order to highlight the methodology followed by the authors to unravel the basin paleo-geometry. In this study, the maximum burial depth (middle to upper Miocene) is inferred from the Figure 3.

Figure 3: Sketch of the current-day geometry of the Pelagian platform near the Zaghouan fault (see E-W line location in Figure 1) based on field data and seismic profile analysis. This crosssection is nearly perpendicular to the fold trends related to the Messino-Tortonian Atlas II folding event. Qualitative burial curve is also given for Jebel Garci sampled Cretaceous rocks.

Figure 4: A) VR data plot along a West-East profile and as a function to the Zaghouan major fault distance. B) VR values as a function of formations thicknesses C) Inferred maximum temperature along a similar W-E profile based on vitrinite reflectance-temperature correlations of Vassoyevich et al. (1970) and Tobin and Claxton (2000).

Figure 5: Inferred the maximum burial depth assuming a common geothermal gradient of $30^{\circ} \mathrm{C}$ per km.

Figure 6: A) Paleo-geometry of the Pelagian platform inferred from VR data at the time of middle-upper Miocene maximum burial (Oligo-Miocene basin). These sketches highlight vertical displacement of the Zaghouan fault; note that both kinematics and fault dip is still debated. Sketches showing examples of sampling bias which are assumed in our interpretations. C) Sketch showing how a regional geothermal anomaly could lead to misinterpretation of VR values. Based on literature (see text for references), this latter case has been excluded of our interpretation. Dotted line shows the top of Cretaceous. Atlas II tectonic event occurred at Tortonian/Messinian times and therefore postdates the drawn configurations.

Table 1: Age, sample location, structural domain, Zaghouan Fault Block, lithology, Kerogen type, Total Organic Content for each sample of this study. Kerogen type in bracket (III) corresponds to some terrestrial input in addition to the main type II. Vitrinite reflectance data are given with standard deviation and number of measurements. The temperature calibration is based on vitrinite reflectancetemperature correlations of Vassoyevitch et al. (1970) and Tobin and Claxton (2000).

\section{CONFLICT OF INTEREST}

No conflict of interest declared

\section{REFERENCES}

ALLEN, P.A. \& ALLEN, R.R. (2005) Basin Analysis: Principles and Applications. Blackwell, Oxford, pp. 549.

ANDERSON, J., E., (1991) Subsidence history and structural evolution of the western margin of the Pelagian Platform, central Tunisia. PhD Thesis, Kingston University, UK.

ANDERSON, J.E., (1996) The Neogene structural evolution of the western margin of the Pelagian Platform, central Tunisia. Journal of Structural Geology, 18, 819-833.

ARKAI, P., SASSI, F., DESMONS, J., (2007) Very low- to low-grade metamorphic rocks (Chapter 2.5), in Fettes, D., and Desmons, J., eds., Metamorphic Rocks: A Classification and Glossary of Terms (Recommendations of the International Union of Geological Sciences Subcommission on the Systematics of Metamorphic Rocks): Cambridge, UK, Cambridge University Press, p. 36-42

AUDET, P. \& BURGMANN, R., (2011) Dominant role of tectonic inheritance in supercontinent cycles. Nature Geoscience 4, 184-187 doi: 10.1038/ngeo1080 
BAIRD, A.W., GROCOTT, J., SANDMAN, R.I., GRANT, G.G., MOODY, R.T.J. (1990) A radial reinterpretation of the Tunisian Atlas thrust belt and foreland basin system. International Conference on Thrust Tectonics, Royal Holloway and Bedford New College. Program and Abstracts, 81

BARKER, C.E., PAWLEWICZ, M.J. (1986) The Correlation of vitrinite reflectance with maximum temperature in humic organic matter, in Bhatachajri, S., et al., eds., Lecture Notes in Earth Science, 5. Paleogeothermics: New York, Pringer-Verlag, p.79-93.

BARKER, E., PAWLEWITCZ, M.J. (1994) Calculation of Vitrinite reflectance from thermal Histories and Peak Temperatures: Reevaluation of vitrinite Reflectance, American Chemical Society Symposium series, 570, 216-229.

BAUDIN, F., TRIBOLLARD, N., TRICHET, J. (2008) Géologie de la matière organique : Société géologique de France Vuibert, Paris, P. 1-263.

BEN AYED, N. VIGUIER, C. (1981) Interprétation structurale de la Tunisie atlasique. $C$. $R$. Acad. Sc., Paris, 292, 1445-1448.

BEN DHIA, H. (1987) The geothermal gradient map of Central Tunisia: Comparison with structural, gravimetric and petroleum data: tectonophysics, 142, 15, 99-109

BONINI, M., SANI, F., ANTONIELLI, B., (2012) basin inversion and contractional reactivation of inherited normal faults: A review based on previous and new experimental models. Tectonophysics, 522-523, 55-88, doi:10.1016/j.tecto.2011.11.014.

BOUAZIZ, S., BARRIER, E., SOUSSI, M., TURKI, M., ZOUARI, H., (2002) Tectonic evolution of the Northern African Margin in Tunisia from paleostress data and sedimentary record Tectonophysics, 357, 227-253.

BRAHIM, N. \& MERCIER, E., (2007) Commentaire à la note intitulée « Mise en évidence en subsurface d'événements compressifs Eocène moyen-supérieur en Tunisie orientale (sahel) : généralité de la phase atlasique en Afrique du Nord de Sami Khomsi, Mourad Bédir, Mohamed Soussi, Mohamed Ghazi Ben Jemia et Kmar Ben Ismail-Lattrache, Compte Rendu Geoscience, 338, 41-49.

BUROLLET, P.F. (1967) General geology of Tunisia In: Guidebook to the geology and history of Tunisia (Ed. Martin, L.). Petroleum Exploration Society of Libya, Ninth Annual Field Confeence, 51-58.

BUSTIN, R.M., (1983) Heating during thrust faulting in the rocky Mountains: friction or fiction. Tectonophysics, 95, 309-328.

BUTLER, R. W. H., TAVARNELLI, E. \& GRASSO, M. (2006) Structural inheritance in mountain belts: An Alpine-Apennine perspective. Journal of Structural Geology. 28, 1893-1908.

CASTANY, G. (1951). Etude géologique de l'Atlas tunisien oriental. Ann. Min. et Géol., Tunisie, 8. Thèse Doct. Ės-Sc., Paris

CAVAILHES, T., SIZUN JP., , LABAUME P., CHAUVET A., BUATIER M., SOLIVA, R., MEZRI, L., CHARPENTIER, D., LECLÈRE, H., TRAVÉ, A., C.GOUT, (2013) Influence of fault rock foliation on fault zone permeability: The case of deeply buried arkosic sandstones (Grès d'Annot, SE FRANCE): AAPG Bulletin, 97, 7, 1521-1543. 
EPPELBAUM, L., KUTASOV, I., PILCHIN, A. (2014) Applied geothermics, Lecture notes in Earth System Sciences: Springer-Verlag Berlin, 732p. DOI: 10.1007/978-3-642-34023-9_2

FILLON, C:, HUISMANS, R.S., VAN DER BEEK, P., J.A MUNOZ (2003) Syntectonic sedimentation controls on the evolution of the southern Pyrenean fold and thrust belt: Inferences from coupled tectonic-surface processes models: Journal of Geophysical Research, 118, 1-16

FRIZON DE LAMOTTE, D., MICHARD, A., SADDIQI, O. (2006) Quelques développements récents sur la géodynamique du Maghreb. C. R. Geoscience, 336, 1-10.

FRIZON DE LAMOTTE, D., LETURMY, P., MISSENARD, Y., KHOMSI, S., RUIZ, G., SADDIQI, O., GUILlOCHEAU, F., MICHARD, A., (2009) Mesozoic and Cenozoic vertical movements in the Atlas system (Algeria, Morocco, Tunisia): an overview. Tectonophysics 475, 9-28.

GREEN, P.F., DUDDY, I.R., JAPSEN, P., BONOW, J.M., MALAN, J.A., (2016) Postbreakup burial and exhumation of the southern margin of Africa. Basin research, 1-32, doi: $10.1111 /$ bre. 12167 .

GUILHAUMAU, N., AND DUMAS, P. (2005) Synchrotron FTIR Hydrocarbon fluid inclusion microanalysis applied to diagenetic history and fluid flow reconstruction in reservoir appraisal. Oil and Gas Science and Technology-Rev. IFP, 60, 763-779.

GUIRAUD, R., BOSWORTH, W., (1997) Senonian basin inversion and rejuvenation of rifting in Africa and Arabia: synthesis and implications to plate-scale tectonics. Tectonophysics, 282, $39-82$.

GUIRAUD, R., (1998) Mesozoic rifting and basin inversion along the northern African Tethyan margin: an overview. In: Mc Gregor, D.S., Moody, R. T., J. \& clark-lowes, D.D. (eds) Petroleum Geology of North Africa. Geological Society of London, Special Publications, 132, 217229.

HEZZI, I., (2014) Caractérisation géophysique de la plateforme du Sahel, Tunise nordorientale et ses consequences géodynamique, $\mathrm{PhD}$ thesis, Tunis, $315 \mathrm{p}$.

HOOD, A., GUTJAHR, C.C., HEACOCK, R.L. (1975) Organic metamorphism and the generation of petroleum. AAPG Bulletin, 59, 986-996.

HUANG, W.L. (1996) Experimental study of vitrinite maturation: effects of temperature, time, pressure, water, and hydrogen index, Organic Geochemistry, 24, 233-241.

HUNZIKER, J.C., (1986) The evolution of illite to muscovite: an example of the behavior of isotopes in low-grade metamorphic terrains: Chemical Geology, 57, p-31-40.

International Standard ISO 7404-3:1984, 1984, Methods for the petrographic analysis of bituminous coal and anthracite, Part 3: Method of determining maceral group composition: Geneva, International Organization for Standardization, $4 \mathrm{p}$. 
International Standard ISO 7404-2:1985, 1985, Methods for the petrographic analysis of bituminous coal and anthracite, Part 2: Preparation of coal samples: Geneva, International Organization for Standardization, $8 \mathrm{p}$.

International Standard ISO 7404-5:1994, 1994, Methods for the petrographic analysis of bituminous coal and anthracite, Part 5: Method of determining microscopically the reflectance of vitrinite: Geneva, International Organization for Standardization, $12 \mathrm{p}$.

KETT, T.R., (2001) Total Petroleum Systems of the Pelagian Province, Tunisia, Libya, Italy, and Malta, The Bou Dabbous - Tertiary and Jurassic-Cretaceous Composite. US Department of the Interior, US Geological Survey.

KHOMSI S., M. BEDIR, M. SOUSSI, JEMIA. M. G. BEN, ISMAIL. BEN-LATTRACHE, K., (2006) Mise en évidence en subsurface d'événements compressifs Eocène moyen-supérieur en Tunisie orientale (Sahel) : généralités de la phase atlasique en Afrique du Nord. C. R. Géoscience, 338 4149

KHOMSI, S., GHAZI BEN JEMIA, M., FRIZON DE LAMOTTE, D., MAHERSSI, C., ECHIHI, O., MEZNI, R. (2009) An overview of the Late Cretaceous - Eocene positive inversions and Oligo-Miocene subsidence events in the foreland of theTunisian Atlas: Structural style and implications for the tectonic agenda of the Maghrebian Atlas system. Tectonophysics 475, $38-58$

KUBLER B., JABOYEDOFF, M., (2000) Illite Crystallinity, Compte Rendu Académie des Sciences, Sciences de la Terre et des planètes / Earth and Planetary Sciences 331, 75-90.

LABAUME, P., JOLIVET, M., SOUQUIÈRE, F., CHAUVET, A., (2008) Tectonic control on diagenesis in a foreland basin: combined petrologic and thermochronologic approaches in the Grès d'Annot basin (late Eocene- early Oligocene, French-italian external Alps): Terra Nova, 20, 95-101, doi 10.1111/j.1365-3121.2008.00793.x.

LAFFITE R., (1939) Etude de l'Aurès. Bulletin du Service des Cartes Géologiques Algérie, $2^{\circ}$ série, 15, $484 \mathrm{p}$.

LAUGHLAND, M., UNDERWOOD, M.B., (1993) Vitrinite reflectance and estimates of paleotemperature within the Upper Shimanto Group, Muroo Peninsula, Shikoku, Japan in Underwood, M.B., ed., Thermal Evolution of the Shimanto Belt, Southwest Japan: An example of Ridge-Trench Interaction: Boulder, Colorado, Geological Society of America Special Paper 273, 25-44.

LUCAZEAU, F., BEN DHIA, H., (1989) Preliminary heat-flow density data from Tunisia and the Pelagian Sea. Canadian Journal of Earth Sciences, 26(5), 993-1000, doi:10.1139/e89-080

MAHLMANN, R.F. \& LE BAYON, R. (2016) Vitrinite and vitrinite like solid bitumen reflectance in thermal maturity studies: Correlations from diagenesis to incipient metamorphism in different geodynamic settings, International Journal of Coal Geology, 157, 52-73, doi:10.1016/j.coal.2015.12.008.

MAZUREK M., HURFORD, A.J., LEU, W., (2006) Unravelling the multi-stage burial history of the Swiss Molasse Basin: integration of apatite fission track, vitrinite reflectance and biomarker isomerization analysis, Basin Research, 18, 27-50

MEJRI, F., BUROLLET, P.F., BEN FERJANI, A., (2006) Petroleum Geology of Tunisia: A Renewed Synthesis, ETAP Memoir (Eds.), vol. 22, Tunis, p. 230. 
MELKI, F.; ZOUAGHI, T.; BEN CHELBI, M.; BÉDIR, M. ZARGOUNI, F. (2010) Tectonosedimentary events and geodynamic evolution of the Mesozoic and Cenozoic basins of the Alpine Margin, Gulf of Tunis, north-eastern Tunisia offshore. Comptes Rendus Geoscience, 342, 741-753.

MELKI, F., ZOUAGHI, T., HARRAB, S., CASAS SAINZ, A., BÉDIR, M., ZARGOUNI, F. (2011) Structuring and evolution of Neogene transcurrent basins in the Tellian foreland domain, northeastern Tunisia. Journal of Geodynamics 52, 57-69.

METCALF, J.R., FITZGERALD, P.G., BALDWIN, S.L., MUNOZ, J.A. (2009) Thermochronology of a convergent orogeny: Constraints on the timing of thrust faulting and subsequent exhumation of the Maladeta Pluton in the Central Pyrenean Axial Zone. Earth and planetary Science Letters, 832, 488-503.

MORGAN, M.A., GROCOTT, J., RICHARD, T.J., MOODY, R.T.J. (1998) The structural evolution of the Zaghouan-Ressas structural belt, northern Tunisia. In: Macgregor, D., Moody, T., Clark-Lowes, D. (Eds.), Petroleum Geology of North Africa. The Geological Society of London Special Publication, 132, 405-422.

O'HARA, K., HOWER, J.C., RIMMER, S., (1990) Constraints on the emplacement and uplift history of the Pine Mountain Thrust Sheet, Eastern Kentucky: Evidence from Coal Rank trends. The Journal of Geology, 98, 43-51.

OUTTANI, F., ADDOUM, B., MERCIER, E., FRIZON DE LAMOTTE, F. ANDRIEUX, J. (1995) Geometry and kinematics of the South Atlas Front, Algeria and Tunisia. Tectonophysics, 249, 233-248.

PANIEN, M., SCHREURS, G. \& PFIFFNER, A. (2005) Sandbox experiments on basin inversion: testing the influence of basin orientation and basin fill. Journal of Structural Geology, 27,433445 .

PHILIP, H.; ANDRIEUX, J.; DLALA, M.; CHIHI, L. BEN AYED, N. (1986) Evolution tectonique mio-plio-quaternaire du Fossé de Kasserine (Tunisie centrale) implications sur l'évolution géodynamique récente de la Tunisie. Bulletin de la Société Géologique de France, 8, 5-6, 559-568.

PRICE, L.C., (1983) Geologic time as a parameter in organic metamorphism and vitrinite reflectance as an absolute paleogeothermometer. Journal of Petrology and Geology, 6, 5-38.

RICHERT, J. P. (1971) Mise en évidence de quatre phases tectoniques successives en Tunisie. Notes Serv. Géol. Tunisie, 34115125

RIGANE, A., GOURMELEN, C., (2011) Inverted intracontinental basin and vertical tectonics: The Saharan Atlas in Tunisia: Journal of African Earth Sciences, 61 109-128

ROUVIER, H. (1977) Géologie de l'extrême Nord tunisien: tectoniques et paléogéographies superposées à l'extrémité orientale de la chaîne maghrébine, Thèse Doctorat d'Etat. Université de Paris, Paris, France.

SAADI, J. (1990) Exemple de sédimentation syntectonique au Crétacé inférieur le long d'une zone de décrochement NS.: les structures d'Enfidha (Tunisie nord-orientale). Géodynamique 5, 17-33.

SAKAGUCHI, A., YANAGIHARA, A., UJIIE, K., TANAKA, H., KAMEYAMA, M., (2007) Thermal maturity of a fold-thrust belt based on vitrinite reflectance analysis in the Western Foothills complex, western Taiwan. Tectonophysics, 443, 220-232. 
SCHOLZ, C., (1980) Shear heating and the state of stress on faults. Journal of Geophysical Research, 85, 6174-6184.

STACH, E., MACKOWSKY, M-TH., TEICHMULLER, M., TAYLOR, G.H., CHANDRA, D., TEICHMULLER, R., (1982) Coal Petrology. Gebruder Borntraeger (Berlin - Stuttgart), 535 pp.

SUCHY, V., FREY, M., WOLF, M., (1997) Vitrinite reflectance and shear-induced graphitization in orogenic bels: a case study from the Kandersteg area, Helvetic Alps, Switzerland. International Journal of Coal Geology, 34, 1-20.

SWEENEY, J.J., BURNHAM, K.A. (1990) Evaluation of a simple model of Vitrinite Reflectance Based on, Chemical Kinetics: The American Association of Petroleum Geologists Bulletin, 74, 1559-1570.

THOMAS, W. A. (2004) Genetic relationship of rift-stage crustal structure, terrane 590 accretion, and foreland tectonics along the southern Appalachian-Ouachita orogen. Journal of Geodynamics 37(3-5), 549-563.

TOBIN, C.R., CLAXTON, L. (2000) Multidisciplinary thermal maturity studies using vitrinite reflectance and fluid inclusion microthermometry: A new calibration of old techniques: $A A P G$ bulletin, 84, 1647-1665.

TURKI, M.M. (1985) Polycinématique et contrôle sédimentaire associé sur la cicatrice Zaghouan-Nebhana. Thèse ès-Sc., Univ. Tunis, Revue Sc. Terre, édit. INRST, Tunis, 1988, 262p.

VASSOYEVICH, N. B., KORCHAGINA, N.V., LOPATIN, N.V., CHERNYSHEV, V.V. (1970) Principal phase of oil formation: International Geology Review, 12, 1276-1297.

WAPLES, D.W., (1980) Time and temperature in petroleum formation: Application of Lopatin's method to petroleum exploration. AAPG Bulletin, 64, 351-369.

YUAN, Y., HU, S., WANG, H., SUN, F. (2007) Meso-Cenozoic tectonothermal evolution of Ordos Basin, central China: Insights from newly acquired vitrinite reflectance data and a revision of existing paleothermal indicator data. Journal of geodynamics, 44, 33-46. 
A Cenomanian source rock of the Pelagian Platform in Northern Tunisia. The local name of this formation is "Bahloul". See Cavailhes et al.

\section{$1151 \times 863 \mathrm{~mm}(72 \times 72 \mathrm{DPI})$}

